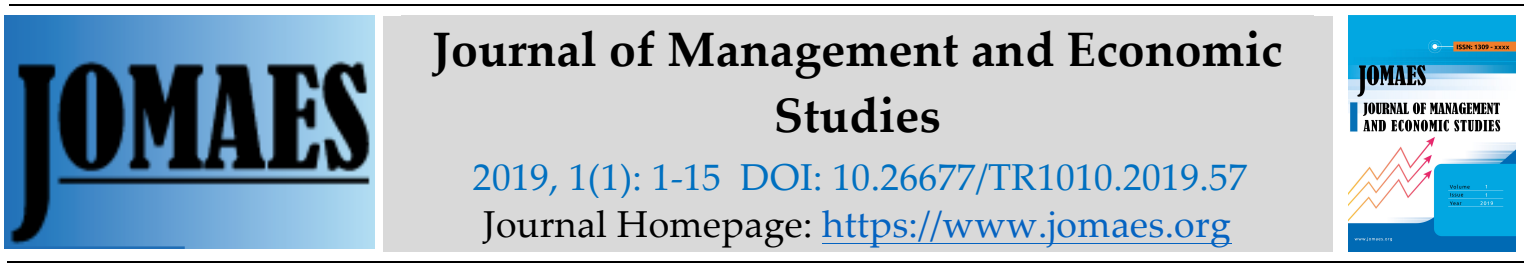

\title{
Industrial Sector Growth And Public Infrastructure Capital In Nigeria
}

\author{
Akatugba D. Oghenebrume \\ Department of Economics,Niger Delta University, Wilberforce Island, Nigeria \\ aka_brume@yahoo.com \\ Francis Agboola Oluleye \\ Department of Economics and Development Studies, Federal University Otuoke, \\ Nigeria, francisoluleye@yahoo.com
}

\begin{abstract}
Public infrastructure is essential for long-run industrial and economic growth. Unfortunately, public infrastructure in most developing countries is typically in poor condition. Poor infrastructure reduces the profitability of modern manufacturing industrial sector and may therefore inhibit industrialization. Road systems are neglected, public transport and telecommunication systems are unreliable, power supply frequently breaks down, hence the need to examine the link between public infrastructure capital and industrial sector growth and through that assess the impact of public infrastructure capital on industrial sector growth in Nigeria. The Ordinary Least Squares (OLS) and the Generalized Method of Moments (GMM) methods were used for the analysis. The empirical results indicate that on one hand, public capital infrastructure captured by infrastructure development index, human capital development measured by human development index and inflation rate are negatively related to industrial sector growth in both the OLS and GMM frameworks. Broad money supply and exchange rate on the other hand, were found to have a positive relationship with industrial sector growth in both the OLS and GMM frameworks. It is thus concluded that for Nigeria, infrastructure exerts a negative impact on industrial sector growth. This outcome suggests that the level of access to infrastructure or its quality did not affect industrial growth. It is therefore recommended that policy direction in Nigeria should focus on reversing pervasive infrastructure deficit, in ways that enable economic growth and development.
\end{abstract}

Keywords: Manufacturing Growth, Public infrastructure, Nigeria.

\section{Introduction}

The insatiable desire to industrialize continues to permeate both developed and developing countries' policy space as industrial development remains a driver of structural change and long-run growth for two reasons as posited by Dijkstra (2000) and Zattler (1996). First, 
industries (especially manufacturing) have higher productivity growth and technological development than other sectors of the economy, and also technological spill over's. Second, countries that neglect industry depend on primary exports which are subject to long-run deterioration of the terms of trade. However, the extent of industrialisation depends on the prevailing macroeconomic environment, the dynamic and complementary nature of economic policies targeted at shifting resources from low productivity to high-productivity sectors. One of the surest ways to achieve the afore-stated goal is through massive investment in public infrastructure capital, as leverage to competitiveness of the industrial sector.

The literature on the impact of public infrastructure capital on growth reports controversial results, as policy makers in Nigeria tend to regard public infrastructure as the key to long-run industrial and economic growth. But unfortunately, public infrastructure in Nigeria is typically in a fairly poor condition. Poor infrastructure reduces the profitability of modern sector manufacturing and may therefore inhibit industrialization. Road systems are neglected, public transport and telecommunication systems are unreliable, power supply frequently breaks down, etc.

Most studies analysing the impact of public infrastructure capital on growth have applied neoclassical production functions (Aschauer, 1989; Garcia-Mila' \& McGuire, 1992; Munnell, 1992; among others). Their results generally point to the positive effects of public capital, but the diversity of results is perhaps too great for any definitive conclusions to be drawn and many inconsistencies have been reported. In this respect, the production function itself has been considered inaccurate due to the restrictions it places on technology and a firm's behaviour, and its failure to take into account private input prices which would affect the intensity of their use. In order to overcome some of these weaknesses, the duality theory has been suggested as an alternative (Berndt \& Hansson, 1992, Nadiri \& Mamuneas, 1994, Morrison \& Schwartz 1996, Conrad \& Seitz, 1992, Seitz \& Licht, 1995 and Sturm, 1997). The duality theory, based on the estimation of cost and profit functions, allows the substitutability relationship between private and public factors to be examined as well as the marginal effect of infrastructure on a firm's cost structure. As stated in Moreno, Lo' pez-Bazo and Art'1s (2002) this approach is of particular relevance to the study of the impact of infrastructure investments.

Moreno, et al (2002) observed that an improvement in the endowment of public capital can have two effects: a short-run effect, due to cost reductions in variable inputs as a consequence of the new public capital stock, where the economy is constrained by its current stock of private capital; and a long-run effect, by which a higher infrastructure endowment changes a firm's desired level of private capital. Thus, the short-run effect of increasing the public capital endowment may be either reinforced or counterbalanced according to the substitutability relationship between public and private capital, in other words, in accordance with the reallocation effect between the two types of capital. This occurs because a firm wishes either to substitute some of its physical capital stock or to increase its intensity with additional free public capital. This might have an influence on the spatial distribution of activity, as pointed out by Martin and Rogers (1995), and might also lead to a sectoral restructuring of the economy, as Holtz-Eakin and Lovely (1996) suggested. 
Furthermore, existing empirical literature on the impact of public infrastructure capital on growth has mainly focused on cross-country time series evidence and a production function framework to estimate the average relation between public infrastructure capital and growth. However, a majority of them focus on one element of infrastructure (e.g., telephone, roads) in disregard of the multidimensional nature of public infrastructure and commonly find that infrastructure stocks are positively related to growth. In addition, empirical tests of the effects of infrastructure on growth use various econometric specifications that depend on the underlying theoretical argument(s) with associated econometric problems. Econometric problems such as simultaneity bias, omitted variables and non-stationarity have not been addressed to varying degrees in subsequent research as studies on Nigeria's infrastructuregrowth nexus are few and scanty. In addition, it is evident from existing empirical literatures that the argument on the nexus between infrastructure and growth is inconclusive and requires a robust approach that would reveal a new insight into the enquiry of infrastructure and growth. It is against this background, that this study takes a different approach by examining the link between public infrastructure capital and industrial sector growth using alternative measures of infrastructure that combine several of its dimensions. The study attempts to fill these gaps.

Following the introduction, the rest of the paper is structured as follows. Section 2 discusses conceptual issues in infrastructure analysis and the many facets of infrastructure. Section 3 presents a brief review of theoretical and empirical literatures on infrastructure and growth. Section 4 explains the model and data, while section 5 presents the estimation technique for the study. Section 6 discusses the empirical results while section 7 provides the conclusion and policy implication.

\section{Conceptual Issues in Infrastructure Analysis}

The literature defines infrastructure in two basic ways. The broader definition distinguishes a conceptually sensible category of capital stock used by large capital-intensive natural monopolies that in individual countries may or may not be privately owned. The other approach is an expedient one used in research. It identifies infrastructure with the tangible stock owned by the public sector. The literature also notes that, as with any public good, some benefits of infrastructure capital such as improved security, time saving; improved health and a cleaner environment are magnitudes that are difficult to measure and thus are not included in official measures of national output. Hence, it is difficult to relate infrastructure to all of its goals.

\section{Facets of Infrastructure and Conceptual Issues in Infrastructure Analysis}

Broadly, infrastructure serves two major purposes. It provides services that are part of the consumption bundle of residents and is an input into private-sector production, augmenting capital and labour. With regard to its role in augmenting output and productivity, there is conceptual agreement but researchers disagree about magnitudes involved. 
Infrastructure includes highways and roads, mass-transit and airport facilities, education buildings, electricity, gas and water supply facilities and distribution systems, waste treatment facilities, correctional institutions, police, fire service and judiciary. Some infrastructure types do not possess the characteristics of public goods - non-rivalry and non-exclusionary - and thus are private and club goods. Power and water are extant examples of private and club goods. Roads constitute a mixed case of private and club goods. Core infrastructure comprises highways, water, electricity and telecommunications. Public services provided by core infrastructure components may enter directly (intermediate inputs) into private-sector production or even into aggregate production function. These components are expected to contribute most directly to private-sector output.

However, some components of core infrastructure are part of social infrastructure (which counts as a final good). For instance, individuals living in squatter and slums that lack social infrastructure such as water and sewerage systems and electricity can be classified as poor cohorts regardless of movements in their indicators of income and food consumption. Therefore, as a basic consumption good, infrastructure is also a central issue in poverty alleviation strategies. Additionally, infrastructure projects generate large-scale expenditure for public works and thus increases aggregate demand. Infrastructure investments are as well sensitive to income shocks.

Boom times can lead to indiscriminate public spending as can redistributive motives. Conversely, countries that face severe drop in income tend to lean on public capital expenditure programmes since the benefits of infrastructure programmes are spread over a longer term, although the costs or the effects of immediate cut backs occur with a lag. Thus cuts in spending on infrastructure are particularly expeditious for politicians attempting to manoeuvre tight budgetary corners. Given the large scale involvement of governments in infrastructure investment, it is suggested that the patterns of growth in infrastructure stocks may be explained better by political economy rather than by economic efficiency (Canning, 1998 as cited in Ayogu, 2007) even though much of the research in this area have looked to economic efficiency.

\section{Theoretical Literature}

The connection between infrastructure and growth is a major focus of the development literature. Rosenstein-Rodan (1943) analysed the demand side of capital formation and particularly identified one category of physical capital for special attention: social over head capital. Social overhead capital is not only characterized by non-convexities which he called 'generalized external economies', but also establishes vital prerequisites for private-sector investment. This idea subsequently blossomed into the public capital hypothesis-the proposition that public capital stock has significant positive effects on private-sector output, productivity and capital formation.

Much later, Ratner (1983) and Aschauer (1989) linked infrastructure to productivity-slow down in the USA and attempted econometrically to establish empirical evidence of the connection postulated by Rosenstein-Rodan. In another study, Aschauer (1993) observed further that infrastructure provision through public investment should be well taken as factor of production 
just as labour and private capital in the private sector production process. In order to raise productivity growth, countries must boost the existing stock of capital accumulation and at the same time investment abundantly on research and development. Most of the empirical studies in this area have focused on the USA and other developed countries. There were empirical regularities in the findings of these studies that the services provided through public capital are more important in the process of raising production efficiency (Lynde \& Richmond, 1993; Munnell, 1990 and Garcia-Mila \&Guire,1992).

It is instructive to state here that theoretical growth thinking within the neoclassical production functions have been revised to include several variables, notably government spending (infrastructure), human capital, protection of property rights and market distortions (see Barro, 1996). The exogenous growth models have been criticized on several grounds including failure to explain technological progress and cross-country income differences. These deficiencies have motivated the development, and burgeoning empirical applications, of endogenous growth models. Barro (1990), one of the earliest contributors to theoretic endogenous growth modelling, argues that the government's contribution to current production is driven by its flow of productive (infrastructure) expenditure, which can prevent diminishing private-sector capital returns, raise the marginal product of private-sector capital, and these in turn raise the rate of output growth. This motivates the present study's focus on public capital infrastructure and industrial sector growth.

\section{Empirical Issues}

Martina and Rogers (1995) examined the impact of public infrastructure on industrial location when increasing returns are present. Major findings: Trade integration implies that firms tend to locate in countries with better domestic infrastructure. High levels of international infrastructure and strong returns to scale magnify industrial relocation due to differentials in domestic infrastructure or capital endowments. Regional policies which finance domestic infrastructure in a poor country lead firms to relocate in this country. Regional policies which finance international infrastructure in a poor country will lead firms to leave this country. We also analyze the incentives for countries to inhibit industrial relocation.

Ret, Niels, Daniel and Youdi (1994) examined the impact of infrastructure (roads, telecommunications, electricity) on industrial development in Central Java. The spatial distribution of manufacturing industry is analysed by means of both secondary data at the knbupatm level and primary data on 274 firms in various pa \& of Central Java. In addition to demand side factors, infrastructure does indeed play an important role, but local government bureaucratic procedures for obtaining land and permits are also important.

Moreno, Lo' pez-Bazo and Art'1s (2002) presented a theoretical framework for determining the short- and long-run effects of public infrastructure on the performance of manufacturing industries in the Spanish regions. The study derived long-run elasticities by taking into account the adjustment of quasi-fixed inputs to their optimum levels. By considering the impact of infrastructure on private investment decisions, the study found that infrastructure exerts an 
indirect source of influence in the long-run through their effect on private capital, apart from the direct effect on costs in the short-run.

Nedozi, Obasanmi and Ighata (2014) analyzed infrastructure development and economic growth in Nigeria using simultaneous analysis. Two models were specified and analyzed using the OLS method. Findings from the study show that infrastructure constitute a critical part of growth process in Nigeria.

Babatunde, Salius and Oseni (2012) attempted to investigate the impact of infrastructure on economic growth in Nigeria using a multivariate model of simultaneous equation during 1970 to 2010. The study utilized three-stage least squares technique to capture the transmission channels through which infrastructure impacted on growth. The study submitted that infrastructure investment directly impacted on the overall output and indirectly stimulates growth of other sectors.

Olorunfemi (2008) examined the direction and the strength of the relationship between infrastructural services and manufacturing output in Nigeria using time series data from 1981 to 2005. The study used Vector Autoregressive (VAR) model and Granger causality. Results showed that the present transport and electricity service in Nigeria did not cause growth to occur in the manufacturing sector. It was also revealed in the study that telecommunication and education had contributed to the growth in the manufacturing sector. The paper recommended that a centrally coordinated, internally consistent and a holistic approach that would encompass uniform standard, a maintenance culture and a linkage between the various sectors of the economy toward the development of infrastructure services is important to the development of manufacturing sector.

Herranz-Loncán (2007) investigated the impact of infrastructure investment on Spanish economic growth during the period 1850 to 1935 using new infrastructure data and VAR technique. The study showed a strong positive relationship between infrastructure and growth but infrastructure returns were not significant in the estimation.

Seitz and Licht (2007) examined the impact of public infrastructure capital on manufacturing production cost in the 11 (West) German states. The study adopted a simple theoretical model of a cost-minimizing firm in which the stock of public capital is included as a proxy for public services provided to firms as a fixed unpaid factor of production. Duality theory was used to recover the productivity effects of public infrastructures by calculating the cost-saving effects that are associated with public services. Using a translog cost function, the study presented a panel estimates for the manufacturing industry in the 11 states of (West) Germany with labour, buildings and machinery as private factors of production. The results strongly indicated significant cost reducing effects of public infrastructure services and suggest that public capital formation encourages private investment.

Kodongo and Ojah (2016) in a study titled does infrastructure really explain economic growth in Sub-Saharan Africa used System GMM to estimate a model of economic growth augmented by an infrastructure variable, for a panel of 45 Sub-Saharan African countries, over the period 
2000-2011. They found that it is the spending on infrastructure and increments in the access to infrastructure that influence economic growth and development in Sub-Saharan Africa. Interestingly, these significant associations, especially those of infrastructure spending, are more important for lesser developed economies of the region than for the relatively more developed economies, which uncommonly have better than near-zero access to infrastructure. In addition to these robust direct links between the target variables, The study further found that infrastructure access, and quality, also relate to economic growth indirectly via export diversification (trade competitiveness), and cross-border capital flows and trade competitiveness, respectively. They recommended reversing Africa's pervasive infrastructure deficit, in ways that enable economic growth and development, must be carefully nuanced.

Ogunlana, Yaqub and Alhassan (2015) analyzed the effect of public and private investment on infrastructures and its impact on economic growth in Nigeria during the period 1970 to 2014 using the Engel-Granger (1987) cointegration and Error correction mechanism (ECM). Empirical results showed that infrastructure components exert positive contribution on economic growth in Nigeria. Domestic investment on infrastructure and total labour force correlated with economic growth negatively. The study recommended that government need to design an economic policy that would raise the quality of infrastructures and at the same time makes provisions for human capital development for sustained growth.

Ehizuelen (2016) examined the dynamic linkages between infrastructure and economic growth in Nigeria. Economic development in Nigeria can be facilitated and accelerated by the presence of infrastructure. The study employed Ordinary Least Squares. Results showed that infrastructure is an integral part of Nigeria economic growth. Undermining it (infrastructure) is undermining the growth and development of Nigerian economy. The study has showed that infrastructure is an intermediate goods and service for the real sector and a finished goods and service for consumers. So, if the real sector which is the engine of growth is to propel Nigerian growth and development, infrastructure should be given qualitative and adequate attention.

\section{Methodology}

\section{Sources of Data and Measurement of variables}

The paper used times series data covering the period of 2000-2016, obtained from World Bank's African Development Indicators, Central Bank of Nigeria (CBN) Statistical Bulletin various issues and National Bureau of Statistics. The choice of this period is predicated on the fact that the study core measure of infrastructure development, that is; the Africa Infrastructure Development Index (AIDI) for Nigeria first edition was published in April 2011. This was updated and expanded to cover the period 2000-2016 (AfDB, 2013b). Seven variables were used in the study, namely industrial sector growth, one proxy of public capital infrastructure, human development index, broad money supply, exchange rate, and inflation rate.

Industrial sector growth was measured as industry production index. This is an economic report that measures changes in output for the industrial sector of the economy. 
Public capital infrastructure was measured by Africa Infrastructure Development Index (AIDI) for Nigeria. The first edition was published in April 2011. This was updated and expanded to cover the period 2000-2016 (see AfDB, 2013b).

Human capital was measured by human development index as reported in the United Nations Development Program (UNDP). UNDP's human development index is composed of life expectancy, national income, and average and expected years of schooling

Broad money supply was used measure the depth of financial development. This is considered important for growth especially in low-income countries like Nigeria. Exchange rate was used to measure the level of economic competitiveness; while inflation measure price stability.

\section{Model Specification}

The main objective of this study is to examine the impact of public infrastructure capital on industrial sector growth in Nigeria. For this purpose the model adapted for this study is predicated on the endogenous growth framework of Barro (1990) and a modified model of Kodongo and Ojah (2016). The preferred model is represented as equation 1 below:

$$
\operatorname{InIPI}=\beta_{0}+\beta_{1} \operatorname{In} P K I+\beta_{2} \operatorname{In} H C D+\beta_{3} \operatorname{InInBMS}+\beta_{4} \operatorname{InEXR}+\beta_{5} \operatorname{InINFR}+\mu
$$

Where,

IPI represents industrial sector growth, PKI public capital infrastructure, while HCD, BMS, EXR, INFR and $\mu$ represent human development index, broad money supply, exchange rate, and inflation rate and the stochastic error term respectively. The a'priori' expectations are determined by the principles of economic theory and refer to the expected relationship between the explained variable and the explanatory variable(s). It is expected that $\beta_{1}$ to $\beta_{4}>0 \& \beta_{5}<0$.

For the necessity of uniformed scale of measurement and consistent interpretation of results, all variables were transformed to natural logarithms, which allow us to interpret the coefficients as elasticities.

\section{Justification of the Variables in the Model}

To capture public capital infrastructure, the study utilized Africa Infrastructure Development Index (AIDI) for Nigeria. This measure is adopted in the present study for many reasons. For instance, measuring infrastructure as a single variable, either in physical or monetary unit fails to capture the multi-dimensional nature and heterogeneity of infrastructure across time periods and countries, and does not properly distinguish between quality/productivity and bulk of infrastructure (Calderón \& Servén, 2010). Additionally, simultaneity can be a serious econometric problem in infrastructure-growth studies because countries with faster growing output may spend more on infrastructure while infrastructure provision may also positively mediate the relationship between aggregate input and output, and hence foster output growth. 
These flagged issues inform our variable measurement and choice of econometric procedures. That is, we tried to respond to the criticism about the use of single variable measures by applying an index of various infrastructure measures. The African Infrastructure Development Index (AIDI), developed by AfDB (2013b), is a weighted average of nine indicators of infrastructure covering four key components: electricity, trans- port, information and communications technology (ICT), and water and sanitation. Although the index emphasizes measures of infrastructure "bulk", it also captures some aspects of infrastructure "quality". For instance, bulk of transport infrastructure is captured through total road network in $\mathrm{km}$ (per square $\mathrm{km}$ of exploitable land area) while transport infrastructure quality is addressed through total paved roads ( $\mathrm{km}$ per10, 000 inhabitants).

Human capital is important because it enables a country's pool of labour resources to acquire hard skills (e.g., ability to operate machines) and soft skills (e.g., for teamwork and effective communication) which can potentially improve the productivity of capital (Kodongo \& Ojah, 2016).

Another factor that could positively affect the industrial sector growth in Nigeria is the steady flow of money supply. Broad money supply as one of the proxies of financial development is considered important for economic growth especially in low-income countries (e.g., Hassan, Sanchez., \& Yuc, 2011; Menyah, Nazlioglu \& Wolde-Rufael, 2014).

Exchange rates (local currency units per unit of the USA dollar) is expect to have a positive and significant effect on industrial sector growth since it has the potential to alter the value of prices in the economy without real changes in the production of goods and services within the economy (Arthur, Aigheyisi \& Oaikhenan, 2015). It is expected that depreciation would reduce import as a result of the higher relative price of imported goods. Depreciation would thus increase net export and domestic income (output) would increase with depreciation through the goods market

Inflation as a measure of price stability is expected to adversely affect consumer demand and adversely affect growth (Kodongo \& Ojah, 2016).

\section{Estimation Technique and Procedure}

First, the variables employed in the study were investigated for their stochastic properties, using two traditional unit roots tests. The traditional tests deployed are the Augmented DickeyFuller (ADF) and Phillips-Perron (PP). The two tests were used to test for consistency and where conflicts exist, to decide on the most appropriate option (see Hamilton, 1994). The unit root tests are followed by Ordinary Least Square (OLS) and the Generalized Method of Moments (GMM). The instruments are the one period lag of the variables. The GMM framework help in dealing with validity of inference, serial correlation effects and the problem associated with endogeneity (see Kodongo \& Ojah, 2016). 


\section{Empirical Results}

\section{Descriptive Analysis}

In order to have glimpse of the data used in the study, a first pass at the data in form of descriptive statistics was carried out. This gives us a good idea of the patterns in the data and the nature of the estimations and diagnostics to be carried out. The summary statistics is presented below.

Table 1: Summary Statistics Results

\begin{tabular}{lllllll}
\hline & IPI & PKI & HCD & BMS & EXR & INFR \\
\hline Mean & 124.0919 & 13.75563 & 0.477275 & 17.11142 & 139.7287 & 17.57688 \\
Std. Dev. & 15.90176 & 4.230814 & 0.018976 & 8.083803 & 22.99285 & 6.030155 \\
Skewness & 0.468010 & 0.131690 & -0.247241 & 1.824208 & 0.472921 & 0.160833 \\
Kurtosis & 1.906969 & 1.430245 & 1.892080 & 4.818086 & 2.929342 & 2.313512 \\
Jarque-Bera & 1.380565 & 1.689001 & 0.981333 & 11.07758 & 0.599739 & 0.383156 \\
Probability & 0.501434 & 0.429772 & 0.612218 & 0.003931 & 0.740915 & 0.825655 \\
Observations & 16 & 16 & 16 & 16 & 16 & 16 \\
\hline
\end{tabular}

Source: Researchers' computations (2017).

As observed from the table, exchange rate has the highest mean value of 139.7287 , while human capital development has the lowest mean value of 0.477275 whereas the mean values for industrial production (IPI), public capital infrastructure (PKI), broad money supply (BMS) and inflation rate (INFR) are 124.0919, 13.75563, 17.11142 and 17.57688 respectively. The analysis was also fortified by the value of the skewness and kurtosis of all the variables involved in the model. The skewness is a measure of dispersion away from the mean value while the kurtosis is a measure of the symmetry of the histogram. The bench mark for symmetrical distribution i.e. for the skewness is how close the variable is to zero. From this study, it can be observed that all the variables are positively skewed except human capital development that is negatively skewed. Variables with value of kurtosis less than three are called platykurtic (fat or shorttailed) and all variables except BMS qualified for this during the study period. On the other hand, variables whose kurtosis value is greater than three are called leptokurtic (slim or long tailed) and BMS variable qualified for this during the study period. Jarque-Bera test shows that the residuals are all normally distributed but with the exception of BMS variable since the probability values do not exceed $5 \%$. In summary, the descriptive statistics revealed that five variables are normally distributed. This is so because the probability values of the variables do exceed $5 \%$.

\section{Time Series Properties of the Variables}

Econometric studies have shown that most financial and macro-economic time series variables are non-stationary and using non-stationary variables leads to spurious regression (Engel \& Granger, 1987). Thus, the variables were investigated for their stochastic properties, using two traditional unit roots tests. The traditional tests deployed are the Augmented Dickey-Fuller (ADF) and Phillips-Perron (PP). The two tests were used to test for consistency and where 
conflicts exist, to decide on the most appropriate option (see Hamilton, 1994). The results of unit root tests are presented in Table 2 below:

Table 2: Unit Root Test Results (Trend and Intercept)

\begin{tabular}{lllllll}
\hline Variables & ADF & $\begin{array}{l}\text { Critical } \\
\text { Values }\end{array}$ & $\begin{array}{l}\text { Order } \\
\text { Integration }\end{array}$ & of & $\begin{array}{l}\text { Critical } \\
\text { Values }\end{array}$ & $\begin{array}{l}\text { Order of } \\
\text { Integration }\end{array}$ \\
\hline IPI & -7.171 & $-5.125^{*}$ & $\mathrm{I}(1)$ & -4.982 & $-4.800^{*}$ & $\mathrm{I}(1)$ \\
PKI & -3.608 & $-3.363^{* *}$ & $\mathrm{I}(0)$ & -2.833 & $-2.690^{*}$ & $\mathrm{I}(1)$ \\
HCD & -4.016 & $-3.791^{* *}$ & $\mathrm{I}(1)$ & -5.756 & $-4.800^{*}$ & $\mathrm{I}(1)$ \\
BMS & -3.145 & $-3.098^{* *}$ & $\mathrm{I}(1)$ & -3.135 & $-2.690^{*}$ & $\mathrm{I}(1)$ \\
EXR & -2.587 & $-1.966^{* *}$ & $\mathrm{I}(0)$ & -4.728 & $-3.759^{*}$ & $\mathrm{I}(1)$ \\
INFR & -4.629 & $-3.791^{* *}$ & $\mathrm{I}(1)$ & -9.007 & $-4.800^{*}$ & $\mathrm{I}(1)$ \\
\hline
\end{tabular}

Note: ${ }^{*}$ Indicates stationary at the $1 \%$ level, and ${ }^{* *}$ Indicates stationary at $5 \%$ level.

Source: Researchers' Computations Using E-views 9.5.

From Table 2, the traditional tests of the ADF and PP indicates that all the variables tend to be stationary in first difference except PKI and EXR which tends to be stationary at level in the ADF test. Next, the study presents the estimated regression results from the OLS and GMM.

Table 4: Regression Results

\begin{tabular}{|c|c|c|c|c|c|c|}
\hline \multicolumn{7}{|c|}{ Dependent Variable: ASI } \\
\hline & OLS & & & GMM & & \\
\hline Variable & Coefficient & t-Statistic & $\mathrm{p}$-values & Coefficient & $\mathrm{t}$-Statistic & p-values \\
\hline $\mathrm{C}$ & $2.438^{* *}$ & 2.248 & 0.04 & $2.499^{* *}$ & 5.131 & 0.04 \\
\hline LOG(PKI) & $-0.535^{* *}$ & -2.704 & 0.02 & $-0.656^{*}$ & -3.328 & 0.00 \\
\hline LOG(HCD) & $-1.194^{* * *}$ & -1.772 & 0.10 & $-0.876^{* * *}$ & -2.085 & 0.06 \\
\hline LOG(BMS) & 0.068 & 1.132 & 0.28 & 0.076 & 1.128 & 0.29 \\
\hline LOG(EXR) & $0.571^{* *}$ & 2.757 & 0.02 & $0.681^{*}$ & 4.273 & 0.00 \\
\hline LOG(INFR) & -0.047 & -0.452 & 0.66 & -0.073 & -0.592 & 0.57 \\
\hline $\mathrm{R}^{2}$ & 0.89 & & & & 0.88 & \\
\hline Adjusted $R^{2}$ & 0.83 & & & & 0.82 & \\
\hline D.W & 1.7 & & & 1.6 & & \\
\hline F. Statistic & $15.91(0.00)$ & & & & & \\
\hline
\end{tabular}

Note: ${ }^{* * *}$ and ${ }^{* * *}$ denote significant at the 1,5 and 10 percent level respectively.

Source: Researchers' Computations (2017).

Results, reported in Table 4, show a strong negative relationship between the target variable infrastructure indexes - and industrial sector growth in both the OLS and GMM frameworks. Consequently, a rise in infrastructure exerts a negative impact on industrial sector growth. The coefficient is statistically significant both the OLS and GMM frameworks. This outcome suggests that the level of access to infrastructure or its quality did not affect industrial growth.

The coefficient of human capital measured by human development index is indirectly related industrial sector growth in both the OLS and GMM frameworks and statistically significant at 
the $10 \%$ levels. This outcome is not in conformity with theoretical prediction and the finding of Kodongo and Ojah (2016).

Broad money supply coefficient is positively related to industrial sector output growth in both the OLS and GMM frameworks. Consequently, a rise in broad money supply, captured as a percentage of GDP exerts a positive impact on industrial sector growth. The coefficient is statistically significant in the FMOLS framework. This finding is consistent with apriori expectation and study of Hassan et al., 2011 and Menyah et al., 2014.

The coefficient exchange rate is directly related to industrial sector growth in both the OLS and GMM frameworks and statistically significant at $1 \%$ and $5 \%$ levels respectively. This outcome is in conformity with theoretical prediction, owing to positive adjustment of output in the longrun, and the enhancement in the export earnings resulting from currency depreciation.

The coefficient inflation rate is negatively related to industrial sector growth in the both the OLS and GMM frameworks. Thus, price instability is inimical to the performance of the industrial sector as it discourages accessibility to credit from financial institutions. Specifically, $1 \%$ increase in inflation rate is associated with -0.047 and -0.073 percent decreases industrial sector growth in both frameworks respectively. This finding is consistent with apriori expectation as inflation is expected to adversely affect consumer demand and adversely affect growth (see Kodongo \& Ojah, 2016).

The goodness of fit of the OLS estimate is adequate. About $89 \%$ in the variation in industrial sector growth is due to changes in the regressors; while in the GMM estimates, the explanatory variables employed in the model account for about $88 \%$ changes in industrial sector growth.

Further empirical evidence revealed that at $1 \%$ level of significance the variables collectively influence the variation of industrial sector growth as shown by the F-statistic (15.91), and F. Prob (0.00) in the OLS framework. This is a sign that the model is a non-spurious regression. Finally, Durbin - Watson Statistic is given as 1.7 and 1.6 in both frameworks $(D-W \approx 2$ ) suggests that autocorrelation is unlikely to be a problem. Consequently, the estimated model is confidently relied upon for making inferences and for prediction purpose as utilized in this study.

\section{Conclusion and Policy Implications}

The paper investigates the link between public infrastructure capital and industrial sector growth and through that assesses the impact of public infrastructure capital on industrial sector growth in Nigeria. The Ordinary Least Square (OLS) and the Generalized Method of Moments (GMM) methods were used for the analysis. It is noteworthy that there is a significant difference between the OLS results and those of the GMM.

The empirical results indicate that on one hand, public capital infrastructure captured by infrastructure development index, human capital measured by human development index and inflation rate are negatively related industrial sector growth in both the OLS and GMM frameworks. Broad money supply and exchange rate on the other hand, were found to have a 
positive relationship with industrial sector growth in both the OLS and GMM frameworks. It is thus concluded that for Nigeria, infrastructure exerts a negative impact on industrial sector growth. This outcome suggests that the level of access to infrastructure or its quality did not affect industrial growth. It is therefore recommended that policy direction in Nigeria should focus on reversing pervasive infrastructure deficit, in ways that enable economic growth and development.

\section{References}

African Development Bank (2013b). The Africa Infrastructure Development Index (AIDI). Tunis: African Development Bank,

Aigheyisi, O.S., \& Oaikhenan, H. E. (2015). Investment, government expenditure and unemployment in Nigeria. A Paper Presented At the Annual Conference of the Nigerian Economic Society (NES). Abuja, Nigeria.

Aschauer, D.A. (1989). Is public expenditure productive? Journal of Monetary Economics, 23, 177200.

Aschauer, D.A. (1993). Genuine economic returns to infrastructure investment. Policy Stud. J, 21, 380-390.

Ayogu, M. (2007). Infrastructure and economic development in Africa: A review. Journal of African Economy, 16, 75-126.

Babatunde, O.A., Salisu, A.A., \& Oseni, I.O. (2012). Infrastructure and economic growth in Nigeria: A multivariate approach. Research Journal of Business Management and Accounting, $1(3), 30-39$.

Barro, R.J. (1990). Government spending in a simple model of endogenous growth. Journal of Political Economy 98, 102-125.

Barro, R.J. (1996). Determinants of economic growth: A cross-country empirical study. National Bureau of Economic Research, NBER Working Paper 5698.

Berndt, E.R., \& Hansson, B. (1992). Measuring the contribution of public infrastructure capital in Sweden. Scandinavian Journal of Economics, 94 (0), 151-172.

Calderón, C., \& Servén, L. (2010). Infrastructure and economic development in Sub-Saharan Africa. Journal of African Economy, 19, 113-187.

Canning, F. (1998). A database of world stocks of infrastructure 1950-95. World Bank Economic Review, 12 (3): 529-47.

Conrad, K., \& Seitz, H. (1992). The public capital hypothesis: the case of Germany. Recherches Economiques de Louvain, 58 (3-4), 309-327.

Dijkstra, A.G. (2000). Trade liberalization and industrial development in Latin America, World Development, 28(9), 1567-82.

Ehizuelen, M. M. (2016). The dynamics of infrastructure and economic growth in Nigeria. Journal of Global Economics, 4(1)

Garcia-Mila', T., \& McGuire, T. (1992). The contribution of publicly provided inputs to states economies. Regional Science and Urban Economics, 22, 229-241.

Hamilton, J.D. (1994). Time Series Analysis. New Jersey: Princeton University Press. 
Hassan, M.K., Sanchez, B., \& Yuc, J.S. (2011). Financial development and economic growth: New evidence from panel data. Quarterly Review of. Economics and Finance, 51, 88-104.

Holtz-Eakin, D., \& Lovely, M. (1996). Scale economies, returns to variety, and the productivity of public infrastructure, Regional Science and Urban Economics, 26, 105-123.

Kodongo, O., \& Ojah, K. (2016). Does infrastructure really explain economic growth in SubSaharan Africa?. Review of Development Finance, 6, 105-125.

Lynde, C., \& Richmond, J. (1993). Public capital and total factor productivity, International Economic Review, 34, 2, 401-414.

Martin, P., \& Rogers, C.A. (1995). Industrial location and public infrastructure, Journal of International Economics, 39, 335-351.

Martina, P., \& Rogers, C.A. (1995). Industrial location and public infrastructure, Journal of International Economics, 39, 335-351.

Menyah, K., Nazlioglu, S., \& Wolde-Rufael, Y. (2014). Financial development, trade openness and economic growth in African countries: New insights from a panel causality approach, Economic Model, 37, 386-394.

Moreno, R., Lo' pez-Bazo, E., \& Art'1s, M. (2002). Public infrastructure and the performance of manufacturing industries: short- and long-run effects, Regional Science and Urban Economics, 32, 97-121.

Moreno, R., Lo' pez-Bazo, E., Art'1s, M. (1997). Public capital, private capital and costs of production: Short- and long-run effects, University of Barcelona, Mimeo.

Morrison, C.J., \& Schwartz, A.E. (1996). State infrastructure and productive performance. The American Economic Review, 86 (5), 1095-1111.

Munnell, A. H. (1992). Infrastructure investment and productivity growth. Journal of Economic Perspectives, 6 (4), 189-198.

Nadiri, I., \& Mamuneas, T (1994). The effects of public infrastructure and R\&D capital on the cost structure and performance of US manufacturing industries, The Review of Economics and Statistics, (1), 189-198.

Nedozi, F.O, Obasanmi, J.O and Ighata, J.A. (2014). Infrastructural development and economic growth in Nigeria: Using simultaneous equation, Journal of Economics, 5(3), 325-332.

Ogunlana, O. F, Yaqub, J. O and Alhassan, B. T. (2016). Infrastructure finance and development in Nigeria. Arabian Journal of Business and Management Review, 3(12).

Olorunfemi, S. (2008). Infrastructural services and manufacturing growth in Nigeria: A dynamic analysis. African Economic and Business Review, 6(2).

Ratner, J. (1983). Government Capital and the Production Function for the U.S. Private Output. Economic Letters, 213-21.

Ret, R., Niels, V., Daniel, K., \& Youdi, S. (1994). Infrastructure and industrial development: the case of Central Java. Bulletin of Indonesian Economic Studies, 30(2), 119-32.

Rosenstein-Rodan, P. (1943). Problems of Industrialization of Eastern and South-Eastern Europe. Economic Journal, 53: 202-11.

Seitz, H., \& Licht, G (1995). The impact of public infrastructure capital on regional manufacturing production cost, Regional Studies, 29 (3), 231-240. 
Seitz, H., \& Licht, G. (1995). The impact of public infrastructure capital on regional manufacturing production cost, Regional Studies, 29 (3), 231-240.

Seitz, H., \& Licht, G. (2007). The impact of public infrastructure capital on regional manufacturing production cost, Regional Studies, 29 (3), 231-240.

Sturm, J.E. (1997). The impact of infrastructure capital on the private sector of the Netherlands: An application of the symmetric generalized McFadden cost function Research Memorandum, CPB Netherlands Bureau for Economic Policy Analysis, The Hague.

Zattler, J. (1996). Trade policy in developing countries: A new trade policy consensus? Intereconomics, 31(4), 229-36. 